\title{
PROFESSIONAL FORESTRY EDUCATION IN CANADA ${ }^{\perp}$
}

\section{By J. B. MILLAR}

As an introduction, I want to give you some of the reasons why a resident of Wisconsin has the temerity to discuss and even think of criticizing the forestry schools of Canada. Although it is twenty odd years since I have had direct contact with forestry education in Canada, those same years have been spent working with and observing the work of at least two hundred graduates. Of these men, one hundred and fifty are now, or previously have been, associated with the company I work for. The others are working with Dominion, Federal, State or Provincial Governments, trade associations, private industry, or as consultants, where the contact has been close enough to form an opinion as to their qualifications and ability. Approximately half of the men mentioned above have graduated from Canadian schools and half are American graduates, and in total represent twenty different schools of forestry, which seems to be a fair cross-section of the subject under consideration. That briefly is my justification for appearing on this program today.

Education in any field is bound to be controversial, and forestry education is no exception. I realize that this meeting is not going to settle the question of a required curriculum versus a series of electives, or specialization at the undergraduate level versus post-graduate training. Each school must decide what sort of a graduate it is going to produce and set its course accordingly. At the joint meeting of the CIF-SAF in Montreal last November, a full day was spent on forestry education. I am not going to attempt in ten minutes to summarize what it took the school teachers a whole day to say. For details I refer you to the published reports of that meeting. However it should be obvious that universities are not vocational schools. There is a minimum of time required to develop a reasonably well-trained, competent university graduate. Any reduction in that time means that some subject has been slighted. Likewise specialization in one aspect, or emphasis in one field, if taken as part of the tegular course, must be done at the expense of basic subjects or by providing less training in another branch.

In the United States at the present time we are having quite a discussion on education in the elementary public schools-progressive educationalists versus the old-fashioned fundamentalists. The subject has been debated in articles and correspondence published in the Scientific Montbly, official journal of the American Association for the Advancement of Science. There has been reference to it in the newspapers and courts of several states, including Arizona and California. Some of us believe that many of the progressive systems prevalent in the United States have gone too far, and some of the Canadian schools have copied this trend to the detriment of the pupils. I firmly believe that British schools are doing a better job than either Canadian or American because the basic requirement is still the three R's and the progressives frequently lose sight of this objective. This all applies to grade schools, and it may be thought to be far removed from our subject, but I feel that the same fundamentals should govern the university course.

\footnotetext{
1 A paper prepared for the 1953 Annual Meeting of the C.I.F. at Winnipeg.
}

2 Kizberly-Ciark Corporation, Neenah, Wisconsin. 
After all, we in industry are looking for young graduates well skilled in the basic sciences.

I do not feel qualified to discuss in detail ranger schools and the place of their graduates in industry. In our particular company, we have had very few ranger graduates and there does not seem to be any indication of a change of policy in that regard. We concede that there is a place for ranger schools and a need for this type of training but we, ourselves, have not been able to utilize rangers in our particular organization.

Now to come to the crux of the problem. What does industry expect from the average graduate of a Canadian forestry school? We expect him to have good grounding in the technical subjects pertaining to forestry, including, of course, the sciences and mathematics; we expect him to have ethical characteristics superior to the average of the country; we expect him to have a reasonable degree of common sense and we expect him to be capable of advancement in the practice of his profession, assuming more responsibility as his proficiency increases; and finally we expect him to have more than a passing interest in the affairs of the state and the nation.

Taking these characteristics in order and in more detail, the technical ability of the Canadian forester is excellent. We have been well satisfied with the past product of the forestry schools and question the advisability of changing any curriculum to permit greater specialization. Although our industrial foresters do become highly specialized, we feel that the process of specialization should be gradual, taking place well after graduation and after the neophyte has his feet firmly on the ground.

I am often asked the question: "How do American foresters compare with Canadian?" It is difficult to evaluate the average of a large group with the average of another group because wide variation in ability and training are common to each. In many ways, the differences are insignificant and an American forester is just as much at home with a group of Canadian foresters as a Canadian would be in a meeting of the SAF. Possibly the average American is more interested in wild-life and game management and definitely so as to range management. Up until recent years, a higher proportion of Canadian graduates were going into industrial work and hence logging and utilization held more significance for them. The tremendous strides of industrial forestry in the Southern pine region and the West Coast states have tended to nullify this difference.

The ethical characteristics of the graduate are good. We have found our foresters to be honest, loyal and conscientious. How much of this is due directly to the example set by the professors may be debatable, but we feel that it is significant.

It is obvious from the experience of foresters in private industry that they are capable of adjusting themselves to meet conditions as encountered, they can handle labor, and generally speaking, exhibit good common sense. How far they advance in administrative and executive work depends on themselves, their opportunities, and their fundamental training. At times that training has not been adequate; the technical aspects have been over-emphasized at the expense of the cultural. Specialized professional 
training does not in itself provide the basis for executive advancement. Recently, speaking on this topic, Dr. R. S. K. Seeley, Provost and ViceChancellor of Trinity College, Toronto, defined the requirements as "ability to understand people, discriminating judgment, an ability to size up the essential points of an issue, clarity of expression and flexibility of mind which can see new points of view and has the courage to adopt them." How do your young foresters measure up to this, or to be more crilical, how do you, yourself rate against such a standard? Dr. Seeley's conclusion, quoted in the Financial Post, was that "Industry needs men of administrative ability and the universities have the educational framework to produce them. In partnership they have the resources not only to develop our potentialities in Canada to the full, but to create a society where these potentialities are best administered for the good of all."

There is, however, one sphere of activity where I feel the forestry profession in Canada has failed to live up to its capability. This is in the field of civic responsibility. As technicians, you rate with the best in the world. You are quite content to go off to some remote area and do an excellent technical job, of value to your employer and of benefit to the country. But have you been concerned with the state of the nation, its domestic problems and foreign affairs, the conduct of business in your province, or even municipal activities where you live? You have left that up to the lawyer and doctor, the farmer and the storekeeper. Supposediy you have an education equal to anyone in the country, but is that education well rounded?

At the annual C.I.F.-SAF banquet held last November in Montreal, Dr. A. W. Truman, then President of the University of New Brunswick, gave an outstanding address, pleading for increased study of the humanities by foresters, by engineers, by everyone. But he did not want it to stop there-he wanted these studies to be immediately reflected by action on the part of the technicians-direct action and participation in civic and national affairs.

At times I am inclined to believe that the members of the SAF have gone farther in this direction than have the members of our Institute. I don't think this is due to any concerted action on the part of the Society as a whole, nor does it appear to be due to any special effort by the forestry schools. Perhaps it can be attributed to the basic nature of the American as a citizen in contrast to his Canadian counterpart. Regardless of the cause, we do find graduate foresters in the Congress of the United States, as governors and other offices of state, political and not just as members of the Civil Service.

Apparently somewhere along the way, we, in Canada, have failed to indoctrinate in the new graduate this idea of community service or civic responsibility. Perhaps the fault has been in the schools-too much attention to technical detail and not enough discussion on the principles of citizenship, and the duty of university men to help mold the thinking of the nation. 
We have heard during the past few days that great progress has been made in our profession, but I don't think the public yet knows what forestry really is. Yesterday there were three business men in the elevator with me. I happened to be the only person wearing a Conference badge, and one of these men who looked to be quite competent and well educated, possibly well informed on most subjects, asked: "What is this conference that is going on in the hotel?" I replied: "It is a foresters' conference." He then enquired: "What do you fellows do-cut down trees?" Now I used to hear that thirty years ago, and I had imagined that stage had been passed, but there is at least one man in Winnipeg who still doesn't know that professional foresters do more than cut down trees-we still have a job to do in public education.

This Institute as a unit has not done much for the welfare of the nation-individually yes, collectively no. I realize you have written and published a Statement of Forest Policy. Well and good as far as it went, but how far did it go? The translation of that Policy Statement into action must be done by the individual members of the Institute. The Institute as a body can do little, but it should be a function of the Institute to encourage its members to act. In the final analysis, the value of this Institute to Canada will be the cumulative effort expended by its individual members, specifically you, you and you.

\section{DISCUSSION OF PAPER PREPARED BY J. B. MILLAR}

Dr. G. S. Allen, Dean, Faculty of Forestry, University of British Columbia. In this paper Mr. Millar has expressed satisfaction with the technical phases of forestry education and with the professional attitude and adaptability of the graduate forester, but he has also expressed some dissatisfaction with the cultural and fundamental training of forestry students, having in mind particularly the question as to whether the graduate forester is prepared to take an executive or administrative position in industry or in government or to take his proper place in the affairs of the nation.

As far as the administrative and executive abilities of a graduate forester are concerned, I can't quite agree with Mr. Millar's viewpoint. I feel that a university cannot be expected to train an executive as such. We all know that there are people who show a natural ability for leadership, some at a very early age, and others at rather a later stage in their development. I would say that all the University can hope to do is to help a person develop his natural ability along these lines.

The principle aim of the forest schools is to train professional men. In forestry we need a great many professional men and only a relatively few executives and administrators. Cultural training as such, providing as it does a broad background in the humanities, languages, history and so on, will not necessarily produce an administrator. Therefore, I would argue against the thought that a simple increase of cultural subjects in the forestry curriculum will necessarily lead in that particular direction. Such a 